\title{
Introduction: Arctic transformation and its consequences for environmental impact assessment
}

The Arctic is undergoing social and environmental transformation due mainly to the mega-drivers of economic globalization and climate change that are changing the world everywhere but especially strongly in the Arctic. Up until now, the region has been changed mostly by progressing globalization (which can be defined as '.. . the process of increasing economic, political and socio-cultural connections' (Keskitalo and Southcott 2014)) in all its forms - economic, political, cultural and social - but mostly by economic globalization.

The opening of world trade, especially after the end of the Cold War, together with the creation of the World Trade Organization (WTO) and various regional free trade agreements, have all made the Arctic increasingly accessible to business. In addition, bilateral investment treaties (BITs) have afforded protection for investments in the Arctic states and in their northern regions, for example multinational companies conducting mineral exploitation in various parts of the Arctic. As was concluded in the Executive Summary of the Strategic Assessment of Development of the Arctic, a study focused on the European side of the Arctic, 'Arctic environmental and socioeconomic changes are driven primarily by climate change and the global economy, with demand for resources remaining a key driver of economic developments' (Stępień et al. 2014, p.xiii).

As has been shown by the Arctic Council's 2005 Arctic Climate Impact Assessment (ACIA), the Arctic has warmed at a rate double the global average since the 1970s. Some of the key findings of the ACIA synthesis report point to dramatic transformation processes in the years ahead:

i) The Arctic climate is now warming rapidly and much larger changes are projected; ...

iii) Arctic vegetation zones are very likely to shift, causing wide-ranging impacts;

iv) Animal species' diversity, ranges and distribution will change;

v) Many coastal communities and facilities face increasing exposure to storms; 
vi) Reduced sea ice is very likely to increase marine transport and access to resources;

vii) Thawing ground will disrupt transportation, buildings, and other infrastructure;

viii) Indigenous communities are facing major economic and cultural impacts; ... .

$\mathrm{x}) \quad$ Multiple influences interact to cause increased impacts to people and ecosystems. (ACIA 2004, pp. 10-11)

These impacts of climate change will greatly transform the region, from the types of fauna and flora inhabiting the area and the new economic activities enabled by the diminishing sea ice cover, to all kinds of both adverse but also positive consequences to the people living in the region.

In 2001 the United Nations Environment Programme had already published a report which demonstrated how overwhelming the change will be for the indigenous and other local communities living in the area:

In the last part of the 20th century, the Arctic has been increasingly exposed to industrial exploration and exploitation as well as tourism. The growth in oil, gas, and mineral extraction, transportation networks and non-indigenous settlements are increasingly affecting wildlife and the welfare of indigenous people across the Arctic. A considerable number of species of birds, mammals, and plants have already undergone a reduction in their populations or breeding success, or have been subjected to other types of impact in $15-20 \%$ of the land area of the Arctic. A 2050 scenario was made using reduced, stable, or increased rates of infrastructure growth as compared to the growth between 1940 and 1990. The scenario revealed that at even stable growth rates of industrial development, $50-80 \%$ of the Arctic may reach critical levels of anthropogenic disturbance in 2050, rendering most of these areas incompatible with traditional lifestyles of many subsistence-based indigenous communities. As most of these impacts are related to the establishment of permanent infrastructure and the exploitation of non-renewable resources, the reversibility of the estimated changes in the near future is most unlikely. (UNEP GLOBIO 2001, p. 2)

\section{CONSEQUENCES OF THIS CHANGE TO ENVIRONMENTAL IMPACT ASSESSMENTS}

An Environmental Impact Assessment (EIA) can be defined - at its minimum - as a governmentally controlled procedure by which scientific studies are made of the potential harmful environmental impacts of a proposed activity. All this is done together with the public. Its goals include improving the quality of information to have decision-makers undertake better decisions from the viewpoint of the environment and human societies and raise in general the level of participation of the public in planning the use of the environment. 
EIAs are legal procedures, and the developers or governments are obligated to organize them. Almost all states of the world nowadays have EIAs in place, and so do the eight Arctic states (the Russian Federation, Canada, the United States, Denmark, Norway, Iceland, Finland and Sweden) that are the focus of this book.

Given the (enormous) pace of change in the Arctic, EIAs will be at the forefront of making this increasing industrial and economic development in the region sustainable, both for its vulnerable ecosystems and indigenous and other local communities. Since EIAs apply to all major industrial and infrastructure projects, it is of vast importance to examine how these procedures could be done better in the unique conditions of the Arctic region.

\section{REFERENCES}

ACIA 2004. Impacts of a Warming Arctic, ACIA Overview Report (Cambridge: Cambridge University Press, 2004) [ACIA Synthesis Report], see at http:// www.acia.uaf.edu/pages/overview.html. See also the Arctic Climate Impact Assessment Final Scientific Report, Cambridge: Cambridge University Press, at http://www.acia.uaf.edu/.

Keskitalo, Carina and Southcott, Chris 2014. Chapter 10 'Globalization' in Arctic Human Development Report II: Regional Processes and Global Linkages (eds Gail Fondahl and Joan Nymand Larsen), TemaNord 2014: 567, pp.397-421, available at: http://sdwg.org/wp-content/uploads/2015/02/ AHDRIIFINALREPORT2015-02-24.pdf.

Stępień, A., Koivurova, T. and Kankaanpää, P. (eds) 2014. 'The Strategic Assessment of Development of the Arctic: An Assessment Conducted for the European Union', European Union, available at: http://www.arcticinfo.eu/ images/pdf/SADA_report.pdf.

UNEP GLOBIO 2001. GLOBIO Global Methodology for Mapping Human Impacts: The Arctic 2050 Scenario on the Biosphere and Global Application, United Nations Environment Programme, available at: http://www.globio.info/ downloads/218/globioreportlowres.pdf. 